\title{
PEMETAAN WILAYAH PENGIRIMAN PRODUK UNTUK MENDUKUNG E-COMMERCE STOKIS PT.GEMA ENERGI TOTAL DALAM MELAYANI MITRA KERJA
}

\author{
Ali Ibrahim ${ }^{1}$, Angie Silvanda Herman ${ }^{2}$ \\ ${ }^{1,2}$ Jurusan Sistem Informasi Fakultas Ilmu Komputer Universitas Sriwijaya \\ ${ }^{1}$ aliibrahim@ilkom.unsri.ac.id \\ ${ }^{2}$ silvanda12@gmail.com
}

\begin{abstract}
Abstrak: PT. Gema Energi Total (GET) merupakan perusahaan berbasis bisnis multilevel marketing yang sedang berkembang di Indonesia. Proses penyebaran produk saat ini masih menggunakan cara konvensional dengan menggunakan media sosial. PT. GET menerapkan sistem dropship kepada stokis dan member-nya. Penerapan sistem pemetaan wilayah kirim produk untuk mendukung E-Commerce stokis PT. GET dalam melayani mitra kerja bertujuan untuk menyediakan media penjualan dalam internal bisnis PT. GET secara business to business (B2B) yang dapat memudahkan member dalam memesan produk kepada stokis untuk dikirim ke konsumen akhir. Sistem pemetaan wilayah E-Commerce ini dibangun berbasis web dengan menggunakan metode FAST (Framework for the Application of System Techniques), PHP sebagai bahasa pemograman, dan MySQL sebagai DBMS-nya. Dengan adanya repository data transaksi penjualan dan penyebaran produk maka pihak perusahaan dapat memantau langsung penjualan pada tingkat stokis dan member.

Kata Kunci : E-Commerce, business to business(B2B), PT. Gema Energi Total, stokis, member
\end{abstract}

Abstract: PT. Gema Total Energy is a company based multilevel marketing business that is growing in Indonesia. Product deployment process is still using conventional means using social media. PT. GET applying dropship system to stockist and members. Implementation of regional mapping system to send products to support the E - Commerce stockists PT . GET serve partners in the work aims to provide media sales in the internal business of PT . GET business to business (B2B ) which can facilitate the members in ordering products to stockist to be sent to the final consumer. System mapping of $E$ - Commerce web-based built using FAST (Framework for the Application of Systems Techniques), PHP as the programming language and MySQL as its DBMS. With the repository sales transaction data and dissemination of products then the company can directly monitor sales at the level of stockist and members.

Keywords: E-Commerce, Business to Business (B2B), PT. Gema Energy Total, stockist, member

\section{PENDAHULUAN}

Dunia perdagangan tidak lagi dibatasi oleh ruang dan waktu. Seiring dengan begitu cepatnya perkembangan teknologi informasi di dunia perdagangan, maka persaingan dibidang perdagangan semakin meningkat [1]. Mobilitas manusia yang tinggi menuntut dunia perdagangan mampu menyediakan layanan jasa dan barang dengan cepat sesuai dengan permintaan konsumen. Tidak terkecuali dengan para pelaku bisnis juga menjalankan bisnisnya secara online. Transaksi secara online ini lebih dikenal dengan nama $e$ commerce yang menghubungkan antara produsen dengan produsen, produsen dengan konsumen, konsumen dengan produsen, konsumen dengan konsumen [2]. PT. Gema Energi Total atau disingkat GET merupakan sebuah perusahaan yang 
bergerak dibidang bisnis multilevel marketing yang berkantor pusat di Jalan Boulevard Summarecon, Bekasi. PT. GET mendistribusikan produknya berupa produk kesehatan kulit yang bermerek dagang sabun herbal Amoorea. Saat ini PT. GET telah memiliki lebih dari 20.000 mitra kerja atau member yang berstatus sebagai distributor resmi PT. Gema Energi Total.

Semakin pesatnya pertumbuhan jaringan bisnis, PT.GET juga memberikan kesempatan kepada semua pihak untuk bergabung menjadi agen cabang yang tersebar diseluruh Indonesia. Agen cabang tersebut dinamakan stokis, saat ini sudah berjumlah lebih dari 20 stokis yang tersebar di seluruh Indonesia. Stokis PT.GET menjalankan bisnisnya secara dropship. Dropship adalah sebuah istilah penjualan tanpa harus mempunyai stok pribadi. Dalam hal ini member hanya tinggal memesan barang, kemudian stokis akan mengirim langsung kepada konsumen akhir tanpa perlu barang tersebut tiba ke tangan member. Untuk memberikan pelayanan yang baik kepada member nya PT. GET memberikan akses secara online yang meliputi penginputan kode belanja, pendaftaran member baru dan akses pengecekan komisi bonus untuk setiap member. Hanya saja belum adanya sistem secara online yang melayani transaksi penjualan disetiap stokis PT. GET yang terkoneksi langsung dengan seluruh member yang tersebar. Saat ini member masih melakukan pembelian dengan cara telpon, sms, chatting via bbm kepada stokis yang hanya dimiliki kontaknya saja. Sehingga member kesulitan dalam menentukan wilayah kirim produk kepada konsumen akhir. Dan terjadi ketidakseimbangan pengiriman produk pada wilayah stokis tertentu saja. Member lebih cenderung memilih order barang pada stokis yang sudah dikenal dekat secara pribadi. Sebagai contoh, wilayah stokis pulau Jawa lebih ramai terjadi pengorderan barang dibandingkan dengan stokis-stokis yang berada di luar pulau Jawa. Padahal saat ini member sudah semakin berkembang pesat di seluruh Indonesia. Namun masih belum meratanya ketersediaan barang untuk stokis-stokis di luar pulau Jawa.

Selain itu pihak stokis juga kesulitan mempromosikan lokasi penjualannya secara global kepada seluruh member dikarenakan stokis belum tentu memiliki semua kontak grup leader yang membawahi member disetiap kota. Member diminta untuk mandiri dalam mencari keberadaan atau kontak stokis yang dituju. Untuk mengetahui kontak stokis member biasanya hanya saling bertanya kepada sesama member melalui sms, telepon, dan chat via bbm. Antara member baru dan member lama belum tentu bisa saling memberikan informasi yang jelas tentang lokasi stokis-stokis PT. GET. Hal ini dinilai kurang efektif dalam mendukung bisnis, melihat PT. GET sendiri harus memberikan pelayanan terbaik kepada seluruh member. Perusahaan harus dapat mengatasi penyebaran wilayah produk yang merata.

Dengan adanya pemetaan wilayah kirim produk pada E-commerce model Business to Bussiness (B2B) [3] diharapkan PT. GET dapat terkoneksi langsung kepada semua member untuk penyebaran produk yang maksimal dengan meminimalkan ongkos kirim ke konsumen akhir. Aktivitas e-commerce dilakukan secara interaktif melalui internet yang memungkinkan berbagai pihak bertransaksi tanpa harus saling bertemu dan bertatap muka. Dalam hal ini juga banyak pihak yang dilibatkan. Seperti ekspedisi pengiriman barang yang menjadi sarana wilayah kirim dan wilayah penerima. Sehingga informasi mengenai 
geografi juga dibutuhkan oleh kedua belah pihak. Dengan adanya pemetaan wilayah kirim produk pada e-commerce stokis PT. GET, diharapkan semua transaksi berjalan lebih efisien terhadap wilayah kirim produk. Dimana member dapat lebih cepat memutuskan dari stokis mana produk tersebut akan dikirimkan ke konsumen akhir. Pemetaan merupakan proses pengumpulan data untuk dijadikan sebagai langkah awal dalam pembuatan peta, dengan menggambarkan penyebaran kondisi alamiah tertentu secara meruang, memindahkan keadaan sesungguhnya kedalam peta dasar, yang dinyatakan dengan penggunaan skala peta.

\section{METODOLOGI PENELITIAN}

Pengembangan sistem informasi ini dilakukan dengan menggunakan metodologi proses pengembangan sistem yang bernama FAST (Framework for the Application of System Thinking). Metode FAST ini memiliki beberapa keunggulan diantaranya : (1) Persyaratan bisnis dan desain sistem lebih mudah divalidasi karena adanya model-model sistem; (2) Spesifikasi kebutuhan dianalisis lebih menyeluruh dan didokumentasikan dengan baik; (3) Spesifikasi desain cenderung stabil, solid karena disesuaikan dengan kebutuhan dan fleksibel karena berbasis model; (4) Sistem dapat dikonstruksikan dengan lebih tepat saat pertama kali dibangun dari spesifikasi berbasis model yang menyeluruh dan jelas. Menurut Whitten [4] terdapat 8 (delapan) tahap pengembangan dalam metode FAST, dimana tahapan ini akan dikerjakan secara berurutan sehingga menghasilkan suatu pemahaman yang mendalam mengenai masalah pada sistem yang berjalan serta rancangan sistem yang diusulkan. Berikut ini tahapan-tahapan dalam metode pengembangan sistem dengan FAST :

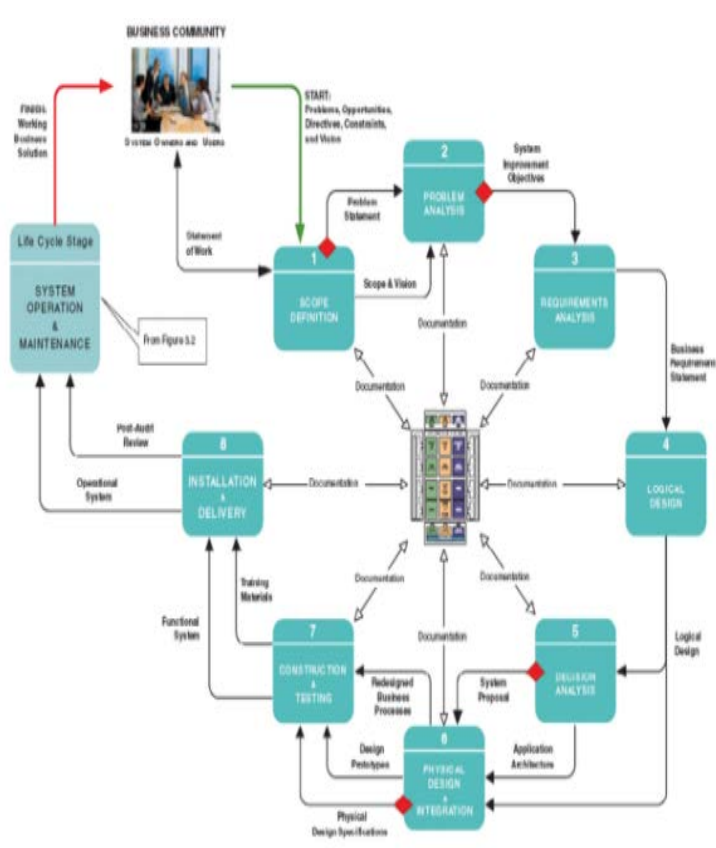

Gambar 1. Metode Pengembangan Sistem FAST[4]

\section{HASIL DAN PEMBAHASAN}

Kegiatan yang berhubungan dengan member pada stokis PT.GET adalah pemesanan barang. Sistem pemesanan yang berjalan saat ini member harus mengontak langsung stokis secara manual dengan cara menelpon, chatting blackberry messenger, dan sms. Hal ini tentunya menyulitkan member yang belum memiliki kontak stokis yang dituju dan member baru yang belum mengerti proses pemesanan barang. Dari observasi yang penulis lakukan dilapangan, masih banyak stokis yang belum memiliki tempat atau kantor khusus untuk penyediaan barang. Sehingga PT.GET menerapkan sistem stokis mobile untuk memenuhi kebutuhan konsumen akhir. Stokis mobile merupakan stokis online tanpa perlu tempat khusus, yang ditawarkan PT.GET kepada member sebagai bentuk kerja sama. Jadi member dapat menjadi stokis dengan cara menyediakan barang dirumah. Dengan menjadi stokis, member berhak ikut serta menanamkan modal atau berinvestor kepada PT.GET. Jumlah modal yang dibutuhkan 
menjadi stokis sebesar Rp 25.080.000 sampai dengan Rp 100.320.000. Selanjutnya PT.GET akan memberikan komisi sebesar 3\% dan 5 \% dari hasil total penjualan stokis. Selain itu dari segi pelayanan, tidak semua stokis merespon dalam waktu yang bersamaan. Hal itu dikarenakan stokis memiliki kesibukan masing-masing diluar jam pelayanan kepada member, sehingga belum maksimal tercapainya integritas sebagai salah satu tujuan bisnis yang diinginkan perusahaan. Dengan sistem pemesanan yang seperti ini tentunya akan merugikan banyak pihak dari segi waktu, biaya, pelayanan, dan kepuasan konsumen. Oleh sebab itu perlu dibangun sebuah sistem pemesanan barang yang dapat mengatasi masalah diatas. Berikut analisis permasalahan:
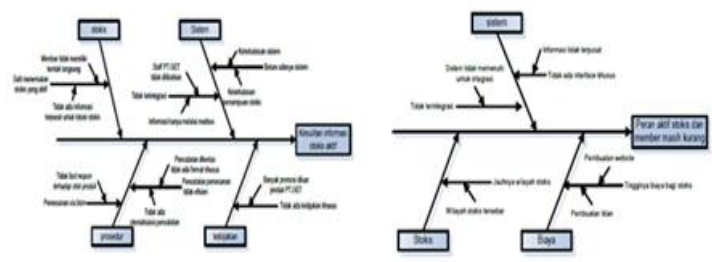

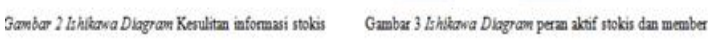
Gambar 2.Diagram Izhikawa

Pada gambar 2 proses pemesanan produk (order), peneliti mengklasifikasikan 4 penyebab yang mengakibatkan terjadinya permasalahan yaitu sistem, stokis, prosedur, dan kebijakan. Pada sistem terdapat 2 cause, yaitu belum adanya sistem, hal ini disebabkan karena keterbatasan kemampuan stokis, keterbatasan sistem, staf PT.GET tidak dilibatkan dan sistem tidak terkomputerisasi. Pada bagian stokis, member sulit menemukan stokis yang aktif dikarenakan tidak ada informasi terpusat mengenai stokis dan memakan waktu pencarian kontak stokis. Sedangkan gambar 3 Pada bagian peran aktif stokis dan member, peneliti mengklasifikasikan 3 penyebab yang mengakibatkan terjadinya permasalahan yaitu sistem, stokis, dan biaya. Pada bagian sistem terdapat 2 cause, yaitu tidak ada interface khusus dan tidak terintegrasi. Pada bagian biaya terdapat satu cause, yaitu tingginya biaya bagi stokis untuk pembuatan iklan mengenai informasi keberadaan lokasi stokis. Sebagian stokis ada yang membuat website, namun tidak terpusat dan terintegrasi dengan sistem, sehingga sifat informasi tidak universal. Pada bagian stokis terdapat satu cause, yaitu jauhnya wilayah stokis. Stokis PT.GET tersebar di seluruh Indonesia, sehingga sistem yang dibangun harus menunjang proses bisnis yang ada.

Dalam menganalisis permasalahan serta penyebabnya digunakan cause and effect analysis matrix sehingga dapat ditemukan inti permasalahan yang sesungguhnya, sedangkan dalam mencari solusi yang sesuai untuk memperbaiki masing-masing permasalahan yang berguna untuk meningkatkan jalannya proses bisnis pada sistem yang diterapkan digunakan system improvement objective matrix, seperti pada tabel 1.

Tabel 1. Analisis Sebab Akibat dan Tujuan Sistem

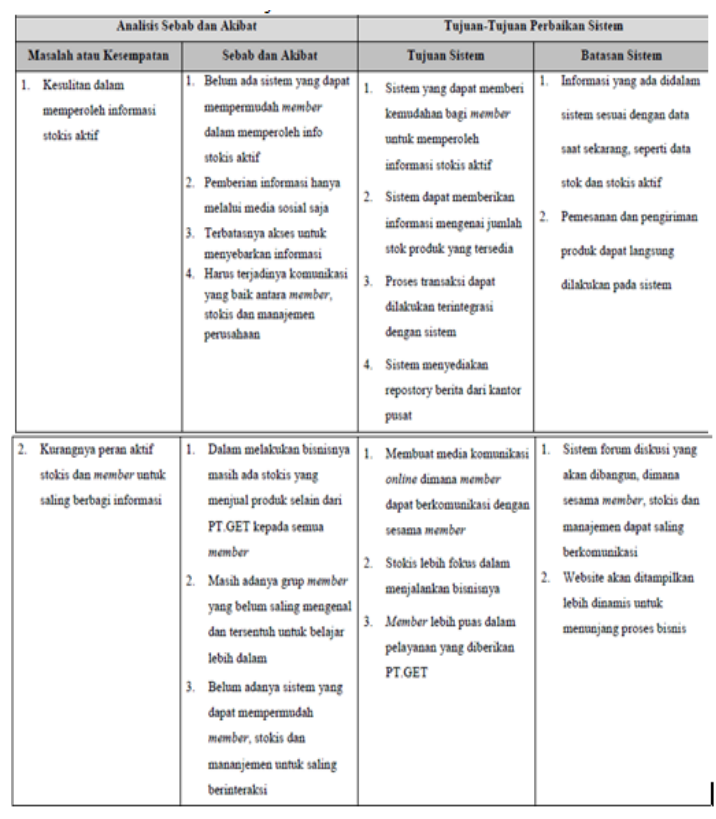

Pada gambar 3 menjelaskan mengenai proses yang akan berjalan pada sistem E-Commerce di 
stokis PT. GET dimana pada sistem ini terdapat 4 entitas yaitu member, stokis, staf pusat dan konsumen akhir.

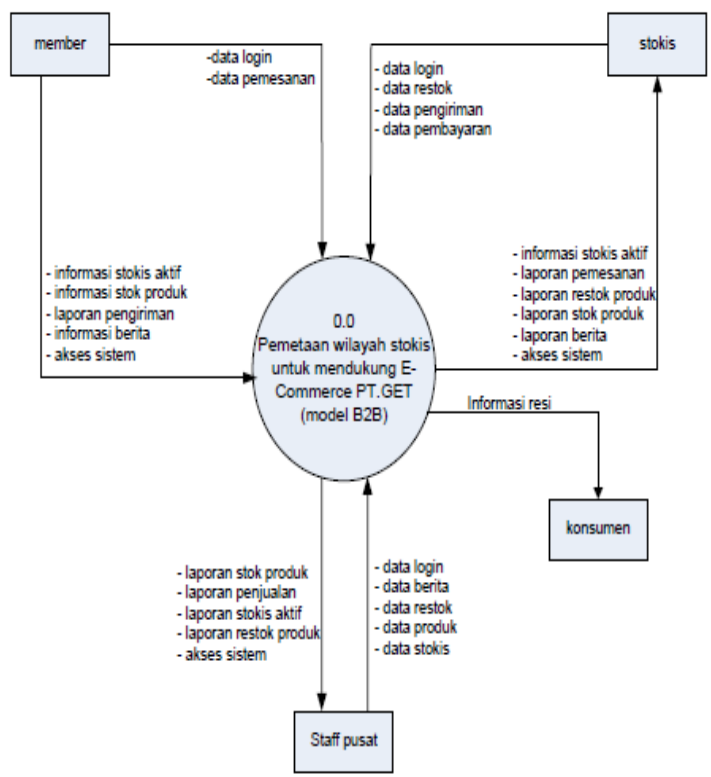

Gambar 3 Diagram Konteks Sistem Pemetaan Wilayah ECommerce

Berikut hasil aplikasi :

Pada gambar 4 terdapat beberapa menu di sisi kanan, yaitu menu data stokis, data pemesanan, data pembayaran, data pengiriman dan keluar. Pada sisi tengah terdapat peta tempat stokis tersebar. Member dapat langsung memesan produk dari link yang tersebar dibeberapa kota. Semua akses pemesanan member terdapat pada gambar 4 .

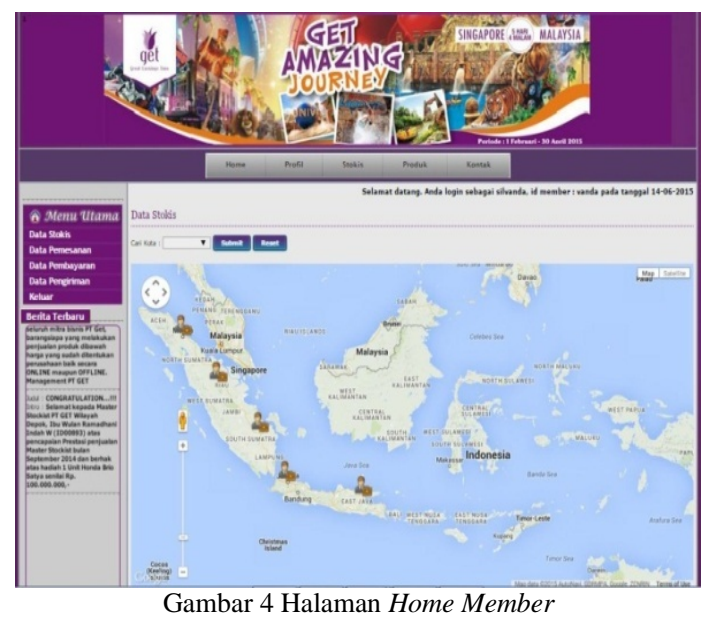

Pada gambar 5 adalah halaman utama stokis ketika berhasil login kedalam sistem. Pada sisi kiri terdapat beberapa menu, yaitu menu data stokis, data pemesanan produk, data pembayaran, data pengiriman, restock barang, pembayaran restock, dan stock barang. Stokis dapat melakukan pemesanan kepada stokis lain. Selain itu stokis juga bisa melakukan restock atau pemesanan produk untuk suplai kepada kantor pusat seperti pada gambar 5 .

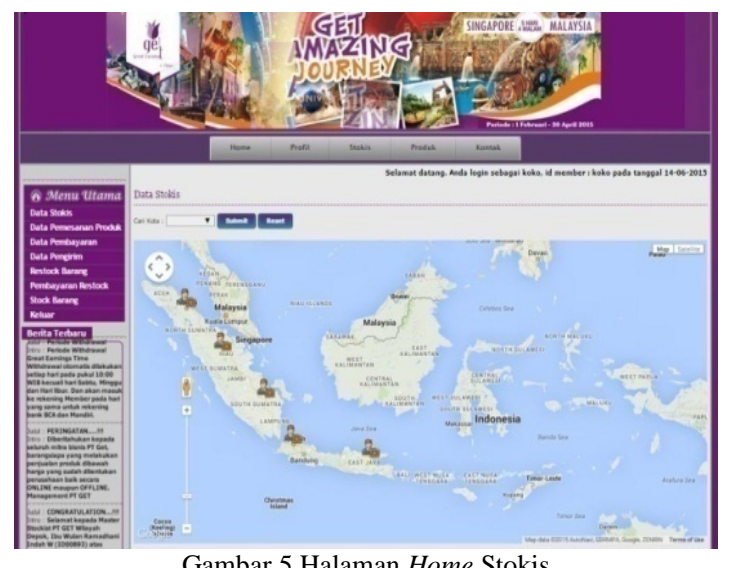

Pada menu data pengiriman, member dapat melihat konfirmasi pengiriman yang dilakukan oleh stokis. Member akan menerima nomor resi pengiriman pada tampilan ini dan mengetahui status pengiriman pada stokis [5], seperti terlihat pada gambar 6.

YTH. Member (username), pemesanan anda telah diproses pengiriman melalui (jasa ekspedisi) dengan nomor resi (no resi). Terimakasih. 


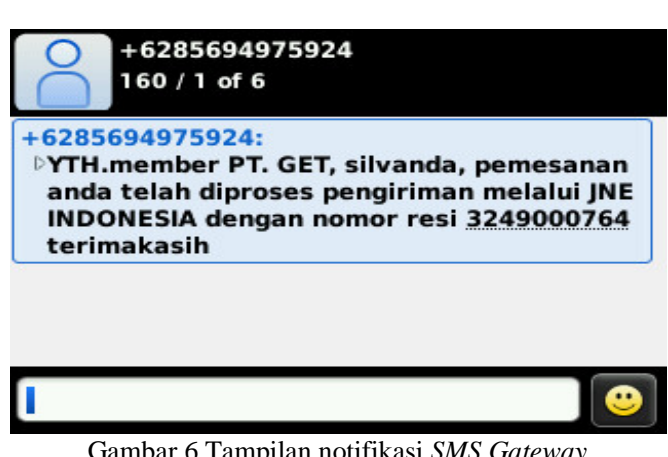

Pada gambar 7 terdapat list menu pada sisi kiri yang membantu staf dalam mengolah data master. Diantaranya data member, data stokis, data produk, data berita, data banner, data bank, data ongkir, restock barang, pembayaran restock, stock produk terupdate saat ini dan beberapa laporan yaitu, laporan data stokis, laporan restock stokis dan laporan penjualan pada stokis.

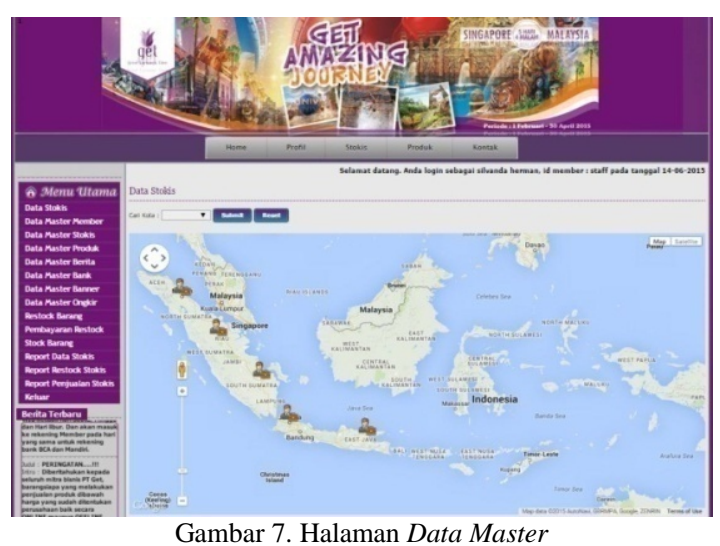

Pengujian sistem oleh User

Untuk mengetahui kelebihan dan kekurangan sistem yang baru diperlukan suatu pengujian terhadap sistem. Teknik pengujian yang digunakan pada sistem informasi agenda kegiatan adalah teknik blackbox. Teknik pengujian blackbox berfokus pada pengujian persyaratan fungsional perangkat lunak. Teknik blackbox mengamati proses masukan dan keluaran dari sistem untuk mendapatkan serangkaian kondisi yang sesuai dengan persyaratan fungsional dan untuk menguji kesesuaian antara desain dengan implementasi program. Berikut ini rekapitulasi tabel hasil pengujian menggunakan blackbox testing.

Tabel 2. Pengujian Sistem E-Commerce dengan metode Blackbox

\begin{tabular}{|c|c|c|c|}
\hline $\begin{array}{l}\text { Peran } \\
\text { Pemakai }\end{array}$ & Kelas Uji & Butir Uji & Hasil \\
\hline $\begin{array}{l}\text { Member, } \\
\text { Stokis, Staf }\end{array}$ & Data login & $\begin{array}{l}\text { Verifikasi data login, username dan } \\
\text { password }\end{array}$ & OK \\
\hline \multirow{3}{*}{ Member } & Kelola data pemesanan & $\begin{array}{l}\text { Input, edit, delete, search data } \\
\text { stokis }\end{array}$ & OK \\
\hline & $\begin{array}{l}\text { Kelolah data } \\
\text { pembayaran }\end{array}$ & Input data pembayaran & OK \\
\hline & Kelola data pengiriman & Menampilkan data pengiriman & OK \\
\hline \multirow{5}{*}{ Stokis } & $\begin{array}{l}\text { Kelola data pemesanan } \\
\text { member }\end{array}$ & $\begin{array}{l}\text { Menampilkan data pemesanan } \\
\text { member }\end{array}$ & OK \\
\hline & $\begin{array}{l}\text { Kelola data pembayaran } \\
\text { member }\end{array}$ & $\begin{array}{l}\text { Menampilkan data pembayaran } \\
\text { member }\end{array}$ & OK \\
\hline & Kelola data pengiriman & $\begin{array}{l}\text { Input, edit, delete, search data } \\
\text { pengiriman }\end{array}$ & OK \\
\hline & Restok produk & $\begin{array}{l}\text { Input, edit, delete, search data } \\
\text { restok produk }\end{array}$ & OK \\
\hline & $\begin{array}{l}\text { Kelola pembayaran } \\
\text { restok produk }\end{array}$ & Input data pembayaran & OK \\
\hline \multirow{9}{*}{ Staff } & Kelola data member & $\begin{array}{l}\text { Input, edit, delete, search data } \\
\text { member }\end{array}$ & OK \\
\hline & Kelola data stokis & $\begin{array}{l}\text { Input, edit, delete, menampilkan } \\
\text { data stokis }\end{array}$ & OK \\
\hline & Kelola data produk & $\begin{array}{l}\text { Input, edit, delete, search data } \\
\text { produk }\end{array}$ & OK \\
\hline & Kelola data berita & $\begin{array}{l}\text { Input, edit, delete, search data } \\
\text { berita }\end{array}$ & OK \\
\hline & Kelola data bank & Input, delete, search data bank & OK \\
\hline & Kelola data banner & $\begin{array}{l}\text { Input, edit, delete, search data } \\
\text { banner }\end{array}$ & OK \\
\hline & $\begin{array}{l}\text { Kelola data ongkos } \\
\text { kirim }\end{array}$ & $\begin{array}{l}\text { Input, edit, delete, search data } \\
\text { ongkos kirim }\end{array}$ & OK \\
\hline & $\begin{array}{l}\text { Kelola data restok } \\
\text { stokis }\end{array}$ & $\begin{array}{l}\text { Menampilkan data restok } \\
\text { pemesanan stokis ke kantor pusat }\end{array}$ & OK \\
\hline & $\begin{array}{l}\text { Kelola data pembayaran } \\
\text { restok stokis }\end{array}$ & $\begin{array}{l}\text { Confirm pembayaran stokis ke } \\
\text { kantor pusat }\end{array}$ & $\mathrm{OK}$ \\
\hline
\end{tabular}

\section{KESIMPULAN}

Berdasarkan penelitian yang dilakukan dan hasil pembahasan yang diuraikan maka dapat ditarik kesimpulan sebagai berikut :

1. Diperlukannya sistem penjualan E-Commerce B2B yang dilengkapi dengan pemetaan wilayah kirim produk dalam proses transaksi penjualan di lingkup bisnis PT. GET agar dapat membantu mitra kerja dalam menjalankan aktifitas bisnisnya.

2. Sistem Pemetaan wilayah penjualan oleh stokis dibangun dalam platform website yang terkoneksi jaringan internet. Member, stokis dan staf pusat dapat mengakses sistem dari mana saja. Tidak terbatas ruang dan waktu penjualan. 
3. Interaksi internal lebih mudah dan efisien, member dan stokis dapat saling bertransaksi dalam sistem online ini.

4. Stokis dapat langsung memesan restock produk ke kantor pusat pada sistem dan dimudahkan dalam mempromosikan wilayah keberadaannya kepada member dalam sistem ini.

5. Dengan adanya sistem pemetaan ini, member dimudahkan dalam pencarian produk dan wilayah kirim. Member dapat langsung memesan sesuai wilayah yang ditujukan.

\section{REFERENSI}

[1] Jane, Kaneth, Lason, Sistem Informasi Manajemen ed 10, Jakarta: Salemba Epat, 2008.

[2] Nugroho, E-Commerce Memahami Perdagangan Modern di Dunia Maya, 1st penyunt., Bandung: Informatika, 2006.

[3] Maidoni, "Penerapan Model B2B Pada Sistem Informasi Berbasis Web (Studi Kasus PT. Semen Baturaja),” Fakultas Ilmu Komputer Universitas Sriwijaya, Palembang, 2010.
[4] L. J. Whitten, Metode Desain dan Analisis Sistem, Indianapolis: ANDI, 2004.

[5] R. A. A. W. Rhyca Putri Ardy, "Pemanfaatan SMS Gateway Dalam Pelayanan Informasi Aktifitas Siswa Pada TK Xaverius 5 Palembang,” p. 3, 2013.

[6] Prahasta, Sistem Informasi Geografi Konsep-konsep Dasar (Perspektif Geodasi dan Geomatika), 1st penyunt., Bandung: Informatika, 2009.

[7] Kadir, Pengenalan Sistem Informasi, Yogyakarta: ANDI, 2003

[8] M.Suyanto, Strategi Periklanan Dalam E-Commerce Perusahaan TOP Dunia, 1st penyunt., Yogyakarta: ANDI OFFSET, 2003.

[9] S. Tzu, Creating Distribution Strategy, Jakarta: Gramedia Pustaka Utama, 2007.

[10] M. Tohar, Membuka Usaha Kecil, Yogyakarta: Kanisius Media, 2007.

[11] W. P. Bambang, Lead To Bless Leader "Kepemimpinan Yang Menjamin Perusahaan Sejahtera dan Karyawan Bahagia", Jakarta: Elex Media Koputindo, 2010.

[12] Al-Fatta, Analisis dan Perancangan dan Perancangan Sistem Informasi untuk Keunggulan Bersaing Perusahaan dan Organisasi Modern, Yogyakarta: ANDI OFFSET, 2007.

[13] J. Taryana Suryana, E-Commerce Menggunakan PHP dan MySQL, Yogyakarta: Graha Ilmu, 2007 